\title{
Responsabilidade civil da União pelos danos causados pela vacina contra a influenza A - Síndrome de Guillain-Barré (SGB)
}

\author{
Union civil liability for damage caused by influenza vaccine - Guillain-Barré \\ Syndrome (Gbs)
}

\author{
Joyceane Bezerra de Menezes* \\ Jamila Araújo Serpa*
}

\section{Resumo}

O presente artigo, intitulado de "Responsabilidade civil da União pelos danos causados pela vacina contra a influenza A - síndrome Guillain-Barré (SGB)", discorre sobre a responsabilidade da União pelo dano sofrido pela pessoa que desenvolve a síndrome Guillain-Barré após a ministração da vacina contra o vírus H1N1. Na construção da análise, avalia-se a aplicação do risco administrativo para justificar a responsabilidade civil da União, procurando identificar e apontar os pressupostos da relação jurídica reparacional em cotejo com as decisões proferidas pelo Superior Tribunal de Justiça nos Recursos Especiais n 1.514.775 - SE (2015/0026515-0) e n 1.388.197 - PR (2013/0099928-9). As referências bibliográficas foram alcançadas através do estudo doutrinário e documental. A metodologia empregada consistiu na análise discursiva investigativa, com alicerce na doutrina, artigos científicos e jurisprudências pertinentes à matéria, com o fito de aprimorar o tema posto.

Palavras-chaves: Responsabilidade civil. Síndrome Guillain-barré. Reparação civil. Vacina.

\section{Abstract}

This article, entitled "Civil liability of the Union for damages caused by the influenza a vaccine - Guillain-Barré Syndrome (SGB)", discussed the Union's responsibility for the damage suffered by the person who develops Guillain-Barré Syndrome after administration of the vaccine against the Influenza virus. In the construction of the analysis, the application of administrative risk is evaluated to justify the civil liability of the Union, seeking to identify and point out the assumptions of the reparational legal relationship in comparison with the decisions made by the Superior Court of Justice in Special Appeals No. 1,514,775 - SE (2015 / 0026515-0) and No. 1,388,197 - PR (2013 / 0099928-9). Bibliographic references were achieved through doctrinal and documentary study. The methodology used consisted of investigative discursive analysis, based on doctrine, scientific articles and jurisprudence relevant to the matter, with the aim of improving the topic.

Keywords: Civil liability. Guillain-barré syndrome. Civil repair. Vaccine.

\section{Introdução}

A síndrome de Guillain-Barré (SGB) é qualificada como uma polineuropatia periférica incomum que causa paralisia e, em casos mais extremados, insuficiência respiratória e óbito. Em geral, manifesta uma doença gastrointestinal ou respiratória superior antecedente e, em casos raros, apresenta-se como sequela da vacina contra a influenza A. As considerações iniciais sobre a correlação entre a vacinação contra a gripe, de origem suína, e o risco de SGB, deram-se a partir de estudos realizados nos Estados Unidos, na década de 1976, uma vez que se constatou o aumento (estatisticamente significativo) do risco da SGB nos 42 dias após ministração da vacina (FERRANI et al., 2011). A partir de então, vários sistemas de vigilância federal passaram a ser mobilizados para garantir segurança ao processo de imunização.

\footnotetext{
Doutorado em Direito pela Universidade Federal de Pernambuco. Mestrado em Direito Constitucional pela Universidade Federal do Ceará. Graduação em Direito pela Universidade de Fortaleza. Pós-Doutorado em Direito Civil pela Universidade do Estado do Rio de Janeiro Professora titular da Universidade de Fortaleza, integrando o Programa de Pós-Graduação Stricto Sensu em Direito. Professora adjunto, nível 4, da Universidade Federal do Ceará - Faculdade de Direito (Departamento de Direito Privado). Advogada. Fortaleza - CE - Brasil. joyceane@unifor.br

** Mestranda em Direito Constitucional pelo Programa de Pós-Graduação Stricto Sensu da Universidade de Fortaleza - UNIFOR. Graduada em Direito pela Universidade de Fortaleza - UNIFOR. Membro do Grupo de Pesquisa em Direito Constitucional nas Relações Privadas, subgrupo "Obrigações, Direitos dos Danos e Tutela da Pessoa". Advogada. Fortaleza - CE - Brasil. E-mail: jamila.serpa@yahoo.com.br.
} 
Em 2009, quando houve uma ameaça de pandemia decorrente dessa doença, o Programa de Infecções Emergentes (EIP) do Centers for Disease Control and Prevention (CDC), nos Estados Unidos, um programa de vigilância ativa, avaliou o risco de SGB em virtude da vacinação contra o $\mathrm{H} 1 \mathrm{~N} 1$. Os resultados dos estudos realizados continuaram apontando uma conexão relevante entre a vacina da influenza $A(H 1 N 1)$ e a SGB, havendo aumento dos casos de SGB em 0,8 casos /1 milhão de vacinados (FERRARINI et al., 2011).

A despeito do risco estimado, as autoridades não recomendaram a suspensão da vacinação, porque a medida imunizatória ainda constitui uma alternativa eficaz para prevenir as doenças graves resultantes do vírus H1N1. Mais graves são a influenza A e B, ou gripe suína, que geraram uma taxa de hospitalização de 222 casos por 1 milhão e a uma taxa de mortalidade de 9,7 por 1 milhão de população. Em 2019, houve 222 óbitos em virtude de complicações decorrentes da gripe suína (BRASIL, 2019c).

No Brasil, a vacina contra a gripe H1N1 é listada pelo Programa Nacional de Imunização, do Ministério da Saúde e enfaticamente recomendada pela União, para os grupos populacionais de crianças entre seis meses e cinco anos, trabalhadores da área de saúde, gestantes e puérperas, indígenas, idosos e professores (BRASIL, 2019c). A campanha específica para a vacina está, em 2019, na $21^{a}$. edição, mantendo os mesmos grupos populacionais na listagem dos prioritários (BRASIL, 2019c).

Em cada um dos informes técnicos dessas vinte e uma edições da campanha de vacinação, há a informação sobre o risco mínimo de síndrome de Guillain-Barré entre os eventos adversos pós-vacinação (EAPV), porém, considerando o binômio risco e benefícios, as autoridades entenderam por não suspender a campanha imunizatória que, a cada ano, alcança um maior número de pessoas. Por outro lado, ainda que os riscos de SGB como EAPV sejam mínimos, não poderá ser compreendido como mera externalidade ou um caso fortuito.

Se é certo que a vacinação é uma medida de especial relevância para o bem da saúde coletiva e individual, também é certo que a sua administração em massa para esse fim não justifica, como uma consequência ordinária, excepcional dano grave a uma pessoa. Sob a perspectiva de quem sofre o dano excepcional, há grave e insuportável injustiça, que impõe o seu enfrentamento pelo instituto da responsabilidade civil. Portanto, EAPV, previamente identificado pelos estudos científicos já realizados, não serão considerados meros casos fortuitos pela doutrina da responsabilidade civil. Constituem dano injusto que deve ser objeto de reparação.

A teoria do risco administrativo impõe que a atividade estatal (lato sensu) não importe em danos ou risco de danos ao cidadão. Na medida em que o exercício dessa atividade resultar em danos, emergirá o dever de indenizar pautado na responsabilidade objetiva, exigindo-se apenas a prova do evento dano e do nexo de causalidade com a citada ação ou omissão administrativa.

É certo que o processo de vacinação pode envolver outros atores que não apenas a União, a exemplo do laboratório que fabrica a vacina e da clínica particular que a aplica, pois nem sempre a sua administração se dá pela rede pública. Mas é importante destacar o protagonismo do Estado quanto ao controle técnico das vacinas pela Agência Nacional de Vigilância Sanitária (Anvisa) e a inclusão no Programa Nacional de Imunização (PNI), com a promoção de campanhas fortemente ativas para mobilizar a população.

No Brasil, as vacinas são objeto da mesma disciplina jurídica atribuída aos remédios, sofrendo ambos o mesmo tipo de fiscalização e controle pela Anvisa. Além disso, a legislação é eloquente em afirmar que toda e qualquer vacina aplicada no país deve ser dotada de inocuidade (Lei $n^{\circ} 6.360 / 76$ e Decreto n. $^{\circ} 79.094 / 77$, este último revogado pelo Decreto $n^{\circ} 8.077 / 2013$ ).

A partir disso, o objeto do presente texto, é analisar a responsabilidade da União pelo dano sofrido pela pessoa que desenvolve a síndrome Guillain-Barré como EAPV. Na construção da análise, avalia-se a aplicação do risco administrativo para justificar a responsabilidade civil da União, procurando identificar e apontar os pressupostos da relação jurídica reparacional em cotejo com as decisões proferidas pelo Superior Tribunal de Justiça nos Recursos Especiais no 1.514.775 - SE (2015/0026515-0) e no 1.388.197 - PR (2013/0099928-9). Como proposta de desenvolvimento, inicia-se pelos estudos científicos que conectaram a vacina à ocorrência da SGB como um possível efeito colateral; em seguida, abordam-se os contornos teóricos da teoria do risco administrativo e os pressupostos da relação jurídica reparacional para, ao fim, analisar as soluções inscritas naqueles recursos especiais. 


\section{Síndrome de Guillain-Barré após a ministração da vacina contra a influenza}

Em 1976, publicaram-se os primeiros estudos associando a SGB como evento adverso da vacina contra a gripe suína, ocasionada pelo vírus (H1N1) (FELINTO et al., 2019). ${ }^{1}$ Quando a doença ameaçava a saúde dos americanos, o Centers for Disease Control and Prevention - (CDC), agência de vigilância epidemiológica dos Estados Unidos, por orientação dos infectologistas então consultados, decidiu instituir uma campanha de vacinação em massa, temendo que a gripe suína pudesse atingir cerca de 60 milhões de pessoas só naquele país. Iniciada a campanha de vacinação em outubro de 1976, os efeitos danosos logo se manifestaram, inclusive quanto às sequelas, como a síndrome de Guillain-Barré (EISEN et al, 2009).

Cerca de quarenta milhões de americanos, incluindo o presidente, receberam a vacina, e cerca de quinhentas pessoas adoeceram, registrando-se 25 mortes como EAPV. A tentativa de cura matou mais que os efeitos da doença que pretendia evitar, e a vacina foi suspensa nos Estados Unidos (SBCM, 2015). Desde então, a vacina contra a gripe tem sido objeto de aprimoramento pelos laboratórios e de severo monitoramento por parte do Programa de Infecções Emergentes (EIP) do CDC.

Em 2009, quando a ameaça de pandemia voltou mais uma vez, a agência americana concluiu novos estudos mostrando que a vacina da influenza A (H1N1) de 2009 ainda mantinha a possibilidade de apresentar a SGB como EAPV, na proporção de 0,8 casos/1 milhão de vacinados (CENTERS FOR DISEASE CONTROL AND PREVENTION, 2010). Informaram que os riscos identificados poderiam ser comparados aos que haviam sido descritos para a vacina da influenza sazonal (aproximadamente um caso/1 milhão de vacinados), mas, mesmo assim, os riscos de SGB como EAPV seriam inferiores àqueles observados na campanha americana de 1976 (FERRARINI et al., 2011).

A SGB é categorizada como uma neuropatia axonal aguda capaz de implicar em diversas sequelas, podendo configurar um distúrbio heterogêneo com formas variantes, a exemplo da síndrome de Miller Fisher, que é caracterizada por oftalmoplegia, ataxia e arreflexia. Pode abranger um grupo de doenças do sistema nervoso periférico que são caracterizadas pela distribuição de fraqueza nos membros que, não raro, causam paraplegia ou tetraplegia, senão a morte (BRASIL, 2019b). ${ }^{2}$

Nos últimos vinte e um anos, o Brasil lançou campanhas nacionais de vacinação contra a influenza, e o Ministério da Saúde publicou os correspondentes informes técnicos, nos quais se previa expressamente a SGB como um efeito possível após a ministração da vacina.

Consta no Informe Técnico da $21^{\text {a }}$ Campanha Nacional de Vacinação contra a Influenza, que a SGB é um dos efeitos adversos, ainda que de rara manifestação. Em geral, os sintomas são evidenciados entre 01 a 21 dias e, no máximo, até seis semanas após a ministração da vacina (BRASIL, 2019c). Enquanto a estimativa da incidência de SGB na população em geral é de 0,6 a 4 casos por 100.000 habitantes ao ano, entre aqueles que tomaram a vacina, a incidência cai para 0,07 a 0,46 casos por 100.000 habitantes ao ano. Os sintomas se manifestam até seis semanas após a sua ministração (BRASIL, 2019b). Embora a SGB seja muito grave, o risco de complicações decorrentes da influenza é muito maior, compensando a sua prevenção pela vacina. Somente no ano de 2019, morreram 222 pessoas de complicações derivadas da gripe influenza A (ZAREMBA, 2019).

Alguns casos de SGB foram registrados no Brasil nos últimos anos, com a possibilidade de terem sido deflagrados em consequência da zica, da dengue ou da vacina contra a influenza. No Rio de Janeiro, foram registrados 15 casos somente em janeiro de 2016, motivando a Secretaria de Saúde do Estado a inscrever a SGB no rol daquelas doenças de notificação compulsória (THOMÉ, 2016).

\footnotetext{
“Em setembro de 2011, a Organização Mundial de Saúde (OMS) padronizou o nome do vírus para "influenza A (H1N1) pdm09". Até agosto de 2010, mês no qual a OMS anunciou a transição do período pandêmico para o pós-pandêmico, foram registrados casos confirmados laboratorialmente em 214 países, com mais de 18.449 mortes pela doença. No Brasil, em 2009, foram notificados 88.464 casos de síndrome respiratória aguda grave (SRAG), dos quais 50.482 foram confirmados como influenza A(H1N1) pdm09, com 2.060 óbitos. No estado do Rio de Janeiro, foram 5.293 casos de SRAG, com 2.777 casos confirmados."

2 "Várias infecções têm sido associadas à síndrome de Guillain-Barré, sendo a infecção por Campylobacter, que causa diarréia, a mais comum. Outras infecções encontradas na literatura científica que podem desencadear essa doença incluem Zika, dengue, chikungunya, citomegalovírus, vírus Epstein-Barr, sarampo, vírus de influenza A, Mycoplasma pneumoniae, enterovirus D68, hepatite A, B, C, HIV, entre outros."
} 
Dados da OMS mostram que os registros de SGB aumentaram em 19\%, no Brasil, do ano de 2015 para 2016, quando o número de pacientes registrados com a neuropatia totalizou 1.708, implicando em cerca de 5 casos identificados por dia.

Ao se admitir a SGB como efeito adverso da vacina, a vítima de tal prejuízo está em face de um dano injusto que, sob a ótica do merecimento de tutela, deve ser indenizado. A bem da saúde pública (interesse coletivo) e da saúde individual, há uma campanha massiva para a vacinação. Eventuais efeitos adversos, porém, não podem ser tratados como mera externalidade, justificando o direito da vítima do infortúnio de pleitear a reparação civil.

Algumas decisões judiciais foram prolatadas em ações/recursos que disputavam reparação de dano pelo desenvolvimento da neuropatia como EAPV. Exemplificativamente, têm-se os autos de Apelação n'001200903.2012.8.26.0445 - TJSP, APL 0037711-60.2012.8.26.0053 - TJSP, APL 3004059-06.2013.8.26.0428, APL 9132228-05.2008.8.26.0000 - TJSP.

\section{Risco administrativo e reparação de dano causado pela vacina contra a Influenza no Brasil: justificativas para a responsabilidade da União}

O art. $37, \S 6^{\circ}$, da Constituição de 1988 , seguindo as constituições anteriores, adota o princípio da responsabilidade do Estado pelos danos que os seus agentes causarem a terceiros. Por seu intermédio, a pessoa jurídica de direito público sempre responderá pelos danos causados a terceiro, independentemente de culpa do servidor, quando houver nexo de causalidade entre a atividade da Administração e o prejuízo sofrido. Se comprovada a culpa ou o dolo do agente, o Estado poderá exercer contra ele o direito de regresso (PEREIRA, 2016). ${ }^{3} \mathrm{~A}$ mesma responsabilidade objetiva se aplica às pessoas jurídicas de direito privado que estiverem desenvolvendo um serviço público. Observa-se um alargamento constitucional do conceito de agente público para os fins da responsabilidade civil, sendo este assim considerado como aquele que age em nome do Estado.

A Constituição, em seu art. $37, \S 6^{\circ}$, adota a teoria do risco administrativo, segundo a qual o dano derivado do funcionamento do serviço público é indenizável, independentemente de haver sido causado por culpa ou dolo, pelo bom ou mau serviço. Basta a prova da relação causal entre o dano sofrido e a ação do agente, ou do órgão, da administração para que a reparação se torne exigível.

Debate mais acirrado envolve a responsabilidade pelos atos omissivos do Estado. Alguns autores, como Celso Antônio Bandeira de Melo (2014), entendem que a responsabilidade do Estado pelo dano associado à conduta omissiva requer a demonstração da culpa ou dolo do agente, consubstanciando-se como subjetiva. Sob sua ótica, se não houve a conduta do Estado quando este deveria agir, houve uma ilicitude que, portanto, requer a prova da culpa.

Na perspectiva de Sérgio Cavalieri (2016, p. 299), a responsabilidade do Estado por conduta omissiva pode receber dois tratamentos distintos, conforme se trate de uma omissão genérica ou omissão específica. Ocorre a omissão genérica quando, naquela hipótese em que o Estado se omite em face de um dever legal geral, como o exercício regular do poder de polícia ou de fiscalização, não se tem, na sua inação, uma causa direta e imediata do dano, embora seja ela concorrente para a sua ocorrência. Nessa medida, sustenta que caberá à vítima provar que a falta do serviço concorreu para a perpetração do dano, pois, "se houvesse uma conduta positiva praticada pelo Poder Público o dano poderia não ter ocorrido" (CAVALIERI FILHO, 2016, p. 299). Mas se o dano tem conexão com uma omissão específica do Estado, que deixa de agir quando tinha o dever legal de fazê-lo para impedir a situação lesiva específica, a responsabilidade civil pela reparação correspondente é objetiva. ${ }^{4}$

Para evitar a demora na prestação jurisdicional em face do prejudicado, a doutrina e jurisprudência recente dispensam a exigência de denunciação da lide para que o Estado possa, adiante, exercer o direito de regresso contra o servidor que agiu com dolo ou culpa. Segundo Caio Mário, "na esteira de tais considerações, a jurisprudência mais recente, em sua maioria, rejeita a denunciação, considerando-a não obrigatória para o exercício do direito de regresso pela Administração, "pois impõe ao autor manifesto prejuízo à celeridade na prestação jurisdicional" (STJ, $1^{a}$ T., REsp 1.089.955, Rel. ${ }^{a}$ Min. ${ }^{a}$ Denise Arruda, julgado em 03.11.2009; STJ, $1^{\text {a }}$ T., AgRg no AREsp 729.071/PE, Rel. Min. Sérgio Kukina, julgado em 18.08.2015; STJ, $2^{\mathrm{a}}$ T., AgRg no REsp 1.404.362/DF, Rel. Min. Assusete Magalhães, julgado em 04.12.2014)."

Dá-se a omissão específica, segundo Cavalieri Filho (2016, p. 198), "quando o Estado estiver na condição de garante (ou guardião) e por omissão sua cria situação propícia para a ocorrência do evento em situação em que tinha o dever de agir para impedi-lo; a omissão estatal se erige em causa adequada de não evitar o dano [...] pressupõe um dever especial de agir do Estado, que, se assim não o faz, a omissão é a causa direta e imediata de não se impedir o resultado." 
Em 2005, o Informativo $n^{\circ} 391$ do STF mostrava a aplicação da responsabilidade subjetiva na hipótese de omissão genérica do Estado. Porém, no ano de 2011, a matéria volta à Corte por meio do Recurso Extraordinário n. ${ }^{\circ} 136861$ e alcança o reconhecimento de repercussão geral. No final do ano de 2019 , o recurso foi posto em fase de julgamento.

Conforme explicação de Caio Mário da Silva Pereira (2016), com os comentários de Gustavo Tepedino, a Constituição Federal, no art. $37, \S 6^{\circ}$, e o Código Civil, no art. 43, não restringem a responsabilidade civil objetiva do Estado apenas aos atos comissivos. Além disso, já há jurisprudência do Supremo Tribunal Federal sustentando a responsabilidade objetiva para danos derivados de atos comissivos ou omissivos do Estado, "desde que demonstrado o nexo causal entre o dano e a omissão do Poder Público" (BRASIL, 2015, p. 9).

De toda sorte, exige-se, repita-se, a demonstração do nexo de causalidade entre a conduta do Estado ou exercente do serviço público e o dano. Assim, esse tipo de responsabilidade também estará sujeita a excludentes, como nas hipóteses de caso fortuito externo (assim considerado como o fato que não guarda qualquer conexão com a atividade desenvolvida pelo agente e, por isso, provoca a ruptura do nexo causal); força maior; culpa exclusiva da vítima e fato de terceiro que não guarda qualquer correlação com a atividade desenvolvida pelo agente.

Cabe-nos, com o presente texto, avaliar a possibilidade de responsabilização do Estado pelos efeitos adversos pós-vacinação, em especial, a síndrome Guillain-Barré, que é listada como uma sequela possível da vacina contra a gripe Influenza. Preliminarmente, se considera que essa vacina traz a possibilidade desse efeito adverso e que está listada no Programa Nacional de Imunizações (PNI) do governo federal. Embora não esteja entre aquelas vacinas de aplicação obrigatória, a União Federal lança campanhas nacionais anuais especificas, fomentando a sua utilização. Garante, inclusive, a sua aplicação gratuita nos postos de saúde àqueles que são considerados público mais vulnerável à doença: idosos, crianças, professores, profissionais de saúde etc. No ano de 2019, houve a $21^{\text {a }}$ Campanha Nacional de Vacinação contra a influenza, que estima imunizar mais de 59 milhões de pessoas (BRASIL, 2019a).

\subsection{O plano nacional de imunização, o controle administrativo sobre as vacinas no Brasil e a campanha pela vacinação contra a influenza}

O Programa Nacional de Imunizações (PNI) foi criado pela Lei n. ${ }^{\circ} 6.259$, de 30 de outubro de 1975, cujo regulamento se faz pelo Decreto $n^{0} 78.231 / 1976$. Constitui o marco das políticas públicas de vacinação no Brasil, a partir de quando se regulamentaram as ações de vigilância epidemiológica, vacinação e notificação compulsória de doenças no país.

Como é anterior à Constituição Federal de 1988 e ao Sistema Único de Saúde (SUS), a Lei n. ${ }^{\circ}$ 6.259/75 atribuiu ao Ministério da Saúde a competência para a elaboração do PNI (art. $4^{\circ}$ ), com a definição e calendário das vacinações, inclusive aquelas de caráter obrigatório, a serem praticadas de modo sistemático e gratuito (art. 27).

É dever do cidadão se submeter, assim como aos menores sob sua guarda ou responsabilidade, à vacinação obrigatória; de sorte que eventual dispensa requererá atestado médico de contraindicação explícita de aplicação da vacina. Com o Estatuto da Criança e do Adolescente (Lei $n^{\circ} 8.069 / 90$, art. 14) reafirmou-se a obrigatoriedade da vacinação das crianças nos casos estabelecidos pelas autoridades sanitárias. Recusar vacinação às crianças tornou-se uma conduta incompatível com o princípio do superior interesse (MINAS GERAIS, 2019). ${ }^{5}$

\footnotetext{
“EMENTA: APELAÇÃO CÍVEL - MEDIDA DE PROTEAÇÃO - DIREITO À SAÚDE - VACINAÇÃO OBRIGATÓRIA - DIREITO COLETIVO - MELHOR INTERESSE DO MENOR - LIBERDADE RELIGIOSA - PONDERAÇÃO. A vacinação consiste não apenas em direito individual, mas em direito coletivo, uma vez que tem por objeto a diminuição, ou até mesmo a erradicação de doenças. A interpretação que se faz é que as normas de regência buscam garantir a saúde do indivíduo e, por consequência, de toda a população, sendo, portanto, algo acima da escolha pessoal, vez que envolve a diminuição da exposição ao risco e ao contágio de determinadas doenças e ainda evita o reaparecimento de doenças consideradas erradicas. Em consideração Ao Princípio Constitucional do Melhor Interesse, não podem os genitores se recursarem a vacinar os filhos quando se busca alcançar o pleno desenvolvimento daqueles, o que, por certo, envolve o direito à saúde em todas as suas formas, incluídas as de prevenção por meio da vacinação. O interesse do menor se sobrepõe a qualquer interesse particular dos genitores. A imposição da imunização não fere o direito à liberdade religiosa, uma vez que não sendo esse absoluto, é passível de ponderação e, assim, não há se falar no direito de escolha dos pais, mas no direito da criança à saúde."
} 
A vacinação contra a influenza tipo A foi encampada pelo $\mathrm{PNI}$, que, por meio da $21^{\text {a }}$ Campanha Nacional de Vacinação contra a Influenza, estabeleceu a meta de vacinar $90 \%$ do público-alvo, que representava, aproximadamente, 59,1 milhões de pessoas. Além dos indivíduos com 60 anos ou mais de idade, estimava-se vacinar as crianças na faixa etária de 6 meses a menores de 6 anos de idade ( 5 anos, 11 meses e 29 dias); as gestantes; as puérperas (até 45 dias após o parto; os trabalhadores da saúde; os professores das escolas públicas e privadas; os povos indígenas; os grupos portadores de doenças crônicas não transmissíveis e outras condições clínicas especiais; os adolescentes e jovens de 12 a 21 anos de idade sob medidas socioeducativas; a população privada de liberdade e os funcionários do sistema prisional.

Para aprimorar a mobilização popular, o governo federal adotou diversas estratégias, entre elas a disponibilização das demais vacinas do Calendário Nacional de Vacinação para atualização da Caderneta de Vacinação da criança e da gestante, buscando o resgate e vacinação de não vacinados, por considerar o risco para as doenças imunopreveníveis, além das baixas coberturas vacinais nesse público.

Cada informe técnico sobre as campanhas nacionais da vacina contra a influenza A informou a SGB como um possível evento adverso pós-vacinação, ainda que em um risco mínimo de ocorrência. O Plano Nacional de Imunização já estabeleceu, inclusive, protocolo próprio com as orientações sobre como agir em face de EAPV, ordenando as seguintes etapas de ações: "a) Detecção, notificação e busca ativa de novos eventos; b) Investigação (exames clínicos, exames laboratoriais, etc.) e; c) Classificação final dos EAPV” (BRASIL, 2010).

A questão é saber se, ao fim e ao cabo, a deteç̧ão de SGB como EAPV em determinada pessoa que tomou a citada vacina implicará em dano passível de indenização pelo Estado ou pelos fornecedores da vacina, sejam laboratório fabricante, seja a clínica particular na qual haja sido feita a sua aplicação.

\subsection{Agentes envolvidos na vacinação contra a influenza A e o protagonismo da União}

Considere-se que a vacina é ministrada gratuitamente para o público alvo nos postos de vacinação que integram o SUS, mas também pode ser utilizada por qualquer pessoa que vier a procurar as clínicas particulares que ofereçam o serviço de vacinação. Ainda que não esteja capitulada entre aquelas que compõem o catálogo da vacinação obrigatória, a vacina contra a influenza A é massivamente divulgada pelo poder público que conclama as pessoas a se vacinarem, oferecendo-a gratuitamente ao público que considera mais vulnerável à doença.

É certo que a vacina é produzida por laboratórios privados e pode ser distribuída não apenas para o Estado, mas também para as clínicas particulares que oferecem o serviço de vacinação mediante pagamento. Há, portanto, uma rede de agentes envolvidos: a União, que gerencia a campanha nacional de vacinação; os demais órgãos da federação, que integram o Sistema Único de Saúde; as clínicas particulares que administram a vacina, mediante pagamento; além dos laboratórios que fabricam a vacina.

A relação entre o consumidor da vacina e as clínicas e laboratórios é qualificada como uma "relação de consumo", estando sujeita à disciplina do Código de Defesa do Consumidor. Uma vez que a vacina esteja em condições adequadas de uso, não haverá como responsabilizar os fornecedores pelos efeitos adversos, se o consumidor houver sido devidamente e previamente informado. Como se sabe, a legislação pode autorizar o lançamento de produtos perigosos no mercado de consumo, desde que se garanta ao consumidor a devida informação sobre os riscos a eles associados. Na falta dessa informação, dá-se o vício de informação (art. $6^{\circ}$, III, e art. 12 do CDC) que dará ocasião à responsabilidade civil do fornecedor (MARQUES, 2004). ${ }^{6}$ Não haverá qualquer ilicitude no fornecimento do produto perigoso, se o consumidor for devidamente informado sobre os riscos.

Porém, mesmo em face da licitude desse fornecimento, a emergência de um dano cuja possibilidade de ocorrência foi previamente informada ao consumidor, justificará a responsabilidade do fornecedor? A considerar a diç̧ão do CDC, é provável que não (art. $6^{\circ}$, III, e art. 12 do CDC).

\footnotetext{
6 Na hipótese de vício de informação, assim considerado, o fornecedor do produto poderá ser chamado a responder pelo dano. Isto é, o dever de informar reporta-se a um dever essencial, dever mínimo, dentro das relações de consumo, ao qual se atribui como ônus ao fornecedor do produto posto em circulação no mercado de consumo (MARQUES, 2004, p. 646).
} 
Não obstante, considerando a integridade do ordenamento jurídico e o merecimento de tutela de certos interesses, é possível sustentar a possibilidade de indenização dos chamados danos injustos. A título exemplificativo, podem-se citar os danos causados pelo consumo do cigarro (FACCHINI NETO, 2016; RIO GRANDE DO SUL, 2007). Mas o foco do presente texto não é exatamente esse, e sim a responsabilidade da União, ente federado que coordena o Sistema Único de Saúde, nos termos dos arts. $6^{\circ}$, § $2^{\circ}, 15$ e 16 da Lei $n^{\circ} 8.080 / 90$, que gerencia o Programa Nacional de Imunização (Lei $n^{\circ} 6.259 / 75$, art. $3^{\circ}$ ) e coordena todas as ações relacionadas à vigilância epidemiológica.

Além dessa atuação específica, é a Agência Nacional de Vigilância Sanitária, o órgão federal responsável por aferir a qualidade das vacinas e autorizar a sua distribuição e aplicação, a semelhança do que faz com os medicamentos em geral.

De acordo com a Lei $n^{\circ} 6.360 / 76$, sujeitam-se às normas de vigilância sanitária, "os medicamentos, as drogas, os insumos farmacêuticos e correlatos, definidos na Lei n. ${ }^{\circ}$ 5.991, de 17 de dezembro de 1973, bem como os produtos de higiene, os cosméticos, perfumes, saneantes domissanitários, produtos destinados à correção estética e outros adiante definidos" (art. $\left.1^{\circ}\right)$. Dispõe a lei, ainda, que o registro de drogas, medicamentos, insumos farmacêuticos e correlatos, seja reconhecido como "seguro e eficaz para o uso a que se propõe, e possua a identidade, atividade, qualidade, pureza e inocuidade necessárias;" (art. 16, inciso II).7

A seguir, o Decreto $n^{\circ} 79.094 / 77$, revogado atualmente pelo Decreto $n^{\circ} 8.077 / 2013$, que regulamenta a Lei $n^{\circ} 6.360 / 76$ no que toca aos mecanismos de controle dos medicamentos, os produtos sujeitos à vigilância sanitária somente poderão ser industrializados e expostos à venda ou lançados no mercado de consumo se registrados no órgão competente (art. 14), que é hoje, a Anvisa. Especificamente em relação às vacinas, exigese que se comprovem a sua finalidade terapêutica, sua eficácia, inocuidade e esterilidade (art. 26). ${ }^{8}$

Se a vacina contra a influenza A vier a sofrer alguma alteração na sua composição, antes de sua aplicação, será necessário renovar a autorização na Anvisa. A título de exemplo, cita-se a Resolução $n^{\circ} 2.714$, de 4 de outubro de 2018, por meio da qual o órgão regulador autorizou a mudança na composição da vacina que foi utilizada na campanha do ano seguinte (2019).

Em virtude desse controle exercido pela agência, a Portaria Conjunta $n^{\circ} 92$ estabelece uma parceria entre a Anvisa e o Programa Nacional de Imunizações (PNI) do Ministério da Saúde, para monitoramento de ocorrência de eventos adversos associados ao uso das vacinas registradas em território brasileiro. É do interesse e da competência da Agência a investigação continuada sobre os efeitos da vacina que ela própria autoriza que seja distribuída e utilizada no país.

Assim, considerando o protagonismo da União no controle da fabricação, registro e distribuição da vacina, bem como na gestão da campanha nacional que estimula a vacinação em massa, pela rede pública ou particular, é de se defender a sua responsabilização pelos efeitos adversos.

\subsection{SGB - EAPV como dano injusto e o merecimento de tutela}

Coube à União e à Anvisa, órgão federal, autorizar o registro e a distribuição da vacina contra a influenza tipo A, mesmo com a ciência do diminuto, mas possível, risco de SGB entre os EAPV. No cotejo dos riscos de doença e óbito causados pelo vírus influenza A e a possibilidade de a vacina ocasionar a deletéria SGB, a União optou por liberar o uso da vacina. Com isso, lança campanhas anuais, conclamando a população a se imunizar, fazendo uso de diversas estratégias para alcançar o maior número de pessoas. Anima a população a se vacinar

7 "Art. 16. O registro de drogas, medicamentos, insumos farmacêuticos e correlatos, dadas as suas características sanitárias, medicamentosas ou profiláticas, curativas, paliativas, ou mesmo para fins de diagnóstico, fica sujeito, além do atendimento das exigências próprias, aos seguintes requisitos específicos: (Redação dada pela Lei $n^{\circ} 10.742$, de 6.10.2003). I - que o produto obedeça ao disposto no Art. 5 , e seus parágrafos; I - que o produto obedeça ao disposto no artigo $5^{\circ}$, e seus parágrafos. (Redação dada pelo Decreto $\mathrm{n}^{\circ} 6.480$, de 1.12 .1977 ). II - que o produto, através de comprovação científica e de análise, seja reconhecido como seguro e eficaz para o uso a que se propõe, e possua a identidade, atividade, qualidade, pureza e inocuidade necessárias; III - tratando-se de produto novo, que sejam oferecidas amplas informações sobre a sua composição e o seu uso, para avaliação de sua natureza e determinação do grau de segurança e eficácia necessários; [...]"

8 "Art. 14. Nenhum dos produtos submetidos ao regime de vigilância sanitária de que trata este Regulamento, poderá ser industrializado, exposto à venda ou entregue ao consumo, antes de registrado no órgão de vigilância sanitária competente do Ministério da Saúde. Art. 26 . O registro dos soros e vacinas ficará sujeito à comprovação: I - Da eficácia, inocuidade e esterilidade do produto, bem como da sua finalidade imunoterápica, dessensibilizante e pirogênica." 
para evitar os nefastos efeitos da gripe suína, mas não oferece a informação, com o mesmo destaque, sobre os possíveis efeitos adversos. É certo que lista cada um dos chamados EAPV no informe técnico de cada campanha, mas não faz a informação chegar efetivamente ao cidadão consumidor. As peças publicitárias evocam apenas os benefícios da vacina.

Assim o faz para não assustar a população e imunizar o maior número de pessoas, no legítimo intento de evitar uma pandemia. No entanto, se um indivíduo específico vier a padecer em decorrência de um EAPV tão grave como o é a SGB, deve-se Ihe garantir a devida reparação, considerando o merecimento de tutela ao interesse ofendido e ainda a omissão de uma informação efetiva quanto à possibilidade desse efeito.

Não há como presumir que o desenvolvimento da SGB seja mera externalidade, um infortúnio possível que deve ser tolerado pelo bem da saúde pública. Trata-se, portanto, de um dano injusto.

Conforme a doutrina italiana, a partir de uma cláusula geral de injustiça do dano, ${ }^{9}$ é possível expandir o âmbito de aplicação da norma positivada de responsabilidade, superando a compreensão de dano injusto como lesão a direito subjetivo absoluto. Segundo explica Massimo Bianca (1994), o dano injusto envolve a ofensa a qualquer direito absoluto ou relativo, e até mesmo a um interesse protegido, consubstanciando-se na ideia de antijuridicidade, assim compreendida como a violação de um interesse merecedor de tutela. ${ }^{10}$ Como não deriva somente da lesão a direito subjetivo, a ideia do dano injusto evoca uma preocupação para com a justiça social, fazendo-se corresponder a uma espécie de lesão à solidariedade social (RODOTÁ, 1967). Dito isso, não se pode tolerar uma lesão exacerbada ao interesse protegido de uma ou algumas pessoas em nome do benefício de todos, por exemplo.

A despeito da liceidade da conduta deflagradora do dano, o ordenamento jurídico determina que a vítima não deve ficar irressarcida. Cita-se o exemplo do art.188, II, c/c art. 930, do Código Civil. Desvincula-se a injustiça do ano da ideia de antijuridicidade para encampar a possibilidade de reparação de danos aos interesses que são dignos de tutela jurídica (MORAES, 2003). Na síntese de Maria Celina Bodin de Moraes (2003, p. 179), "não parece razoável, na legalidade constitucional, estando a pessoa humana posta na cimeira do sistema jurídico, que a vítima suporte agressões, ainda que causadas sem intenção nem culpa, isto é, sem negligência, imperícia ou imprudência." Se a vítima sofreu um dano injustamente, deverá ser indenizada.

Diante desses argumentos, a pessoa que se submete à campanha imunizatória contra a gripe H1N1, guiada pelo chamado da publicidade massiva do governo para o bem da saúde coletiva, uma vez que seja acometida pelo grave efeito adverso da vacina que é a SGB, fará jus à reparação. É o mínimo que se espera em face do interesse protegido que é o próprio valor pessoa, em sua dignidade, integridade, igualdade e liberdade. Injusto será, permitir que sofra grave dano e esse seja interpretado como mera externalidade de uma ação estatal voltada para o bem-estar coletivo.

A ratio do ressarcimento do dano que decorre de atividade lícita, como no exemplo da campanha imunizatória, está na necessidade de salvaguardar interesses que o ordenamento jurídico considera merecedor de tutela mesmo em face de outros que também se comportam no vasto campo da licitude. Em face de interesses igualmente tutelados, como na hipótese, é possível justificar a possibilidade de indenização em face de um eventual dano (USTARROZ, 2014). Para Moraes (2003, p. 181), "a lesão causadora do dano injusto refere-se, diretamente, ao bem jurídico tutelado, ao interesse ou direito da pessoa humana, merecedor de tutela."

Mas como identificar a emergência de um dano injusto decorrente de uma atividade considerada lícita, como a vacinação? É possível seguir a orientação de Pietro Perlingieiri (2011) quanto à ponderação do merecimento

Nesse mesmo sentido, o doutrinador espanhol Luis Diez-Picazo (1999): "O Dano Injusto é, portanto, uma cláusula geral ou um princípio da responsabilidade civil".

10 Tradução livre de Bianca (1994, p. 584-585): A opção tradicional, que inclui a identificação do dano no sentido de lesão a direito subjetivo absoluto, está em conformidade com a orientação da doutrina italiana tradicional, anterior ao código vigente. [...] Uma parte larga da doutrina tem contestado a ideia de fundo da antijuridicidade do dano. Segundo esta corrente de pensamento a injustiça do dano não pressupõe a lesão de um direito porque injusta pode ser a lesão a um interesse de fato, como resulta da crescente ressarcibilidae do prejuízo que prescinde à titularidade de um direito. No original: "L'opinione tradizionale, che intende l'ingiustizia del danno nel senso di lesione di diritti soggettivi assoluti, si conforma all'orientamento della dottrina italiana maturato anteriormente al codice vigente. [...] Una larga parte della dottrina ha invece contestato l'idea di fondo dell'antigiuridicità del danno. Secondo questa corrente di pensiero l'ingiustizia del danno non presupporrebbe la lesione di un diritto poiché ingiusta puó esses anche la lesione di un interesse di fatto, come risulta dal crescente riconoscimento della risarcibilità di pregiudizi che prescindono dalla titolarità di un diritto." 
de tutela. No Brasil, a metodologia proposta pelo professor italiano é difundida e bem explicada por autores como Maria Celina Bodin de Moraes (2003) e Gustavo Tepedino (2013), seguidos por tantos outros, como Anderson Schereiber (2015), Nelson Rosenvald (2019) e Eduardo Nunes de Souza (2014).

Importa balancear os interesses opostos em uma mesma relação jurídica para identificar quais posições jurídicas devem ser prestigiadas em face do conjunto de valores que o ordenamento jurídico pretende realizar. Assim, sem atinar para os sentimentos negativos ou positivos cultivados pela vítima ou pela coletividade em face do dano perpetrado, é necessário identificar se houve lesão a interesse merecedor de tutela, cujo irressarcimento seria contrário ao que o ordenamento jurídico pretende concretizar.

Para evitar decisionismos, recorremos à sistematização proposta por Anderson Schreiber (2015) para identificar, pela ponderação, o merecimento de tutela que o ordenamento jurídico reserva aos interesses da vítima e do responsável pela lesão. Schreiber (2015) sugere quatro momentos para essa análise, nos quais se busca averiguar: $1^{\circ}$ ) se há merecimento de tutela em abstrato para o interesse lesado; $2^{\circ}$ ) se há merecimento de tutela em abstrato para o interesse lesivo; $3^{\circ}$ ) se existe regra de prevalência entre os interesses conflitantes; $4^{\circ}$ ) se inexiste regra de prevalência entre os interesses conflitantes, sugerindo-se ao judiciário a solução do conflito com base no arcabouço valorativo do sistema.

Usaremos o roteiro acima para responder se a vítima de EAPV, na modalidade SGB, sofreu lesão a um interesse merecedor de tutela pela atuação lícita do Estado em promover a massiva campanha de vacinação contra a influenza $\mathrm{A}$, e, se fará jus à indenização.

Primeiramente, é de se indagar se o interesse lesado é merecedor de tutela pelo ordenamento jurídico. No caso, entende-se que sim, porque a lesão incapacitante resultante da vacinação traz, para a vítima, uma diminuição grave de sua mobilidade ou mesmo a morte, impactando a sua integridade psicofísica ou a vida, interesse jurídico protegido pelo ordenamento. A vítima, não raro, sequer foi individual e efetivamente esclarecida quanto aos possíveis efeitos da vacina. Enquanto o registro da vacina e a campanha nacional conclamando a população à imunização tinham por escopo primário garantir o equilíbrio da saúde pública contra uma possível pandemia e, por isso transcendiam os riscos (ainda que mínimos) de efeito deletério, a pessoa que se viu atingida por eventual consequência negativa foi vitimada por esse efeito assimétrico, sofrendo tratamento desigual comparativamente às demais que apenas foram beneficiadas. A conduta lesiva que se justificava na busca do bem comum trouxe prejuízo significativo a uns poucos, atingindo o princípio da igualdade. Na hipótese, também há um malferimento ao princípio da solidariedade constitucional, que não se compraz com tão infeliz assimetria, o que também justificaria a legítima reparação àquele foi lesado injustamente.

No segundo momento, analisa-se se o interesse lesivo é igualmente merecedor de tutela. Sem dúvida que a União poderá sustentar a liceidade de sua conduta em registrar a vacina pelo órgão sanitário e conclamar a população a se vacinar, mesmo em face do possível efeito residual negativo. Na ponderação entre os riscos da vacina e os riscos da doença, os últimos são comprovadamente superiores. Para o bem da saúde pública, a vacina mostra-se um meio eficaz de evitar a pandemia de gripe H1N1. Nessa medida, tem-se uma conduta lesiva assentada em motivos amparados pelo sistema jurídico e adequada à legislação.

Passando ao terceiro momento da ponderação, é de se perscrutar se existe regra legal que estabeleça a prevalência de um dos interesses envolvidos, quais sejam: a dignidade e integridade psicofísica da pessoa vitimada em SGB e a conduta da União em zelar pela saúde pública, autorizando o registro da vacina e gerenciando a campanha nacional de imunização contra a influenza A. A Constituição Federal estabelece a dignidade da pessoa humana como princípio fundamental que lastreia uma verdadeira cláusula geral de tutela. ${ }^{11} \mathrm{~A}$ vacina

11 Na explicação magistral de Gustavo Tepedino (2001, p. 47-48), a dignidade da pessoa humana finda por lastrear uma cláusula geral de tutela da pessoa até mesmo em situações que não estiverem pontualmente positivadas pelo ordenamento jurídico. In verbis: "A prioridade conferida à cidadania e à dignidade da pessoa humana (art. $1^{\circ}$, I e III da CF), fundamentos da República, e a adoção do princípio da igualdade substancial (art. $3^{\circ}, \mathrm{III}$ ), ao lado da isonomia formal do art. $5^{\circ}$, bem como da garantia residual estipulada pelo art. $5^{\circ}, \S 2^{\circ}, \mathrm{CF}$, condicionam o intérprete e o legislador ordinário, modelando todo o tecido normativo infraconstitucional com a tábua axiológica eleita pelo constituinte. Com efeito, a escolha da dignidade da pessoa humana como fundamento da República, associada ao objetivo fundamental de erradicação da pobreza e da marginalização, e de redução das desigualdades sociais, juntamente com a previsão do $\S 2^{\circ}$ do art. $5^{\circ}$, no sentido da não exclusão de quaisquer direitos e garantias, mesmo que não expressos, desde que decorrentes dos princípios adotados do texto maior, configuram uma verdadeira clausula geral de tutela e promoção da pessoa humana, tomada como valor máximo pelo ordenamento." 
citada não está listada entre as obrigatórias e, é certo, pode ser recusada pelas pessoas, inclusive aquelas consideradas como parte do público mais vulnerável. Até mesmo as vacinas consideradas obrigatórias podem ser recusadas se apresentado um laudo médico que justifique a recusa. Porém, in caso, as pessoas foram e, ano a ano, são chamadas pela campanha publicitária federal para se vacinarem e confiam no controle sanitário do Estado sobre os medicamentos e vacina que, segundo a lei, são qualificadas pela inocuidade. Não raro, como referido, sequer são individualmente informadas dos possíveis EAPV. Em tal contexto, a população se submete à imunização, que tem por fim primordial estabilizar a saúde pública e evitar proliferação de doenças endêmicas, e, excepcionalmente, alguns podem ser surpreendidos com a SGB. A nosso ver, em concreto, há prevalência da dignidade e da integridade sobre o interesse que lastreia a conduta lesiva. Não há como sacrificar a integridade psicofísica ou a vida, de uma pessoa ou de algumas, em nome de qualquer interesse público ou coletivo.

Se há um risco calculado e conhecido pela União de que a vacina pode ocasionar a SGB, e isso não é suficiente para impedir o seu registro pela Anvisa ou que o Estado conclame a população à imunização, uma lesão em concreto à integridade de pessoa específica não pode ser interpretada como uma mera externalidade, reitera-se. Configurará um dano injusto e justificará a reparação.

O quarto momento do esquema proposto por Schreiber se aplica apenas aos casos em que não se vislumbra uma regra legal de prevalência entre os interesses conflitantes. Embora entendamos que há essa regra no caso em exame, como ficou claro no passo anterior, seguiremos para a quarta etapa para responder àqueles que entendem que não há a prevalência.

Caso se entenda que não há prevalência legal entre os interesses conflitantes, o Judiciário deverá cotejálos à luz dos valores que norteiam a unidade do ordenamento jurídico. Nessa medida, seguindo para o quarto momento da ponderação proposta por Schreiber, em não havendo regra especifica definidora da prevalência entre os interesses conflitantes, o Judiciário poderá perscrutar a relação de prevalência entre os mesmos interesses à luz da unidade do ordenamento jurídico. Assim, poderá sustentar a primazia da dignidade da pessoa humana e, consequentemente, da integridade psicofísica da vítima afetada em face do interesse coletivo perseguido pela União. Considerando a circunstância específica, o grau de afetação da dignidade e a integridade da vítima são muito superiores.

Na explicação de Celina Bodin de Moraes (2003, p. 179), "o dano será injusto quando, ainda que decorrente de conduta lícita, afetando aspecto fundamental da dignidade humana, não for razoável, ponderados os interesses contrapostos, que a vítima dele permaneça irressarcida." Na página seguinte da mesma obra, complementa: "a simples violação de uma situação jurídica subjetiva extrapatrimonial em que esteja envolvida a vítima, desde que merecedora de tutela, será suficiente para garantir a reparação."

Disso resulta que há, sim, um merecimento de tutela para a vítima de efeito adverso pós-vacinação justificando a sua indenização nos moldes apontados.

\section{A resposta do STJ nos recursos especiais $n .^{\circ} 1.514 .775$ - SE e $n .^{0} 1.388 .197$ - PR}

A emergência da SGB após a ministração da vacina também é reconhecida pela jurisprudência brasileira como uma presunção estimada pelo próprio sistema de saúde, acolhendo o que consta expressamente nos informes técnicos, protocolos e demais documentos.

Coube a essa Corte reconhecer a SGB como um dano injusto quando derivado da vacina contra a influenza A, justificando o pleito reparacional. Cabe-nos analisar, neste tópico, os pressupostos da relação jurídica reparacional e os fundamentos jurídicos adotados nas decisões proferidas nos Recursos Especiais $n$. $^{\circ}$ 1.514.775 - SE (2015/0026515-0) e n. ${ }^{\circ} 1.388 .197$ - PR (2013/0099928-9).

a. Recurso Especial n. ${ }^{0} 1.514 .775$ - SE (2015/0026515-0)

a.1. Julgamento nas instâncias ordinárias

$\mathrm{Na}$ origem, trata-se de ação de reparação por danos materiais e morais proposta por vítima que contraiu a SGB, após campanha de vacinação, contra a União e a empresa Safonis-Aventis, com o objetivo de obter o 
pagamento de pensão mensal de danos materiais, no valor de $R \$ 180.000,00$, e danos morais, no valor de $R \$$ $500.000,00$.

A autora alegou em sua inicial que, em meados de 2008, após receber dose da vacina contra a influenza A em unidade privada, durante a Campanha Nacional de Vacinação contra a Influenza desenvolvida pela União, começou a sentir dificuldades motoras que culminaram na paralisia de seus membros inferiores e superiores, sendo diagnosticada com síndrome de Guillain-Barré. Após adquirir a SGB, aduz que perdeu a sua autonomia e independência, motivo pelo qual retornou à residência de sua mãe, bem como perdeu a capacidade laborativa. Ao final, pugnou pela procedência da ação.

O juízo de primeiro grau decidiu pela improcedência da demanda em razão da responsabilidade ser do fabricante GlaxoSmithKline, e não do demandado Sanfonis-Aventis, uma vez que foi demonstrado nos autos que foi aquele laboratório que produziu a vacina. Ademais, o juízo monocrático afirmou que nenhum agente público atuou na aplicação da vacina, o que se tratava de iniciativa privada, a qual foi realizada pela empresa Intermédica Sistema de Saúde S/A, que, à época, era empregadora da demandante.

Inconformada, a autora recorreu ao Tribunal Regional Federal da $5^{\text {a }}$ Região, pugnando preliminarmente a inclusão no polo passivo do laboratório GlaxoSmithKline (litisconsorte passivo necessário ulterior) e a denunciação da lide da empresa Intermédica Sistema de Saúde S/A; no mérito, requereu a reforma da sentença.

O Tribunal de origem não reconheceu o pleito autoral da inclusão do fabricante GlaxoSmithKline - litisconsorte passivo necessário ulterior, pelo fundamento do princípio da demanda, segundo o qual deveria ter formado o litisconsorte no início da relação processual, de acordo com a relatora desembargadora Margarida Cantarelli. Outrossim, a tese de denunciação da lide não foi aceita, por não estar entre as hipóteses de cabimento do art. 70, do CPC de 1973.

No entanto, o TRF da $5^{\text {a }}$ Região reconheceu a responsabilidade da União, sob o fundamento da ausência de informações, pela citada campanha de vacinação, no sentido de advertir aos destinatários da vacina, bem como toda a população, as possíveis reações adversas à vacinação contra a influenza A. Ademais, afirmou a relatora que a campanha era de iniciativa do Ministério da Saúde, através do Programa Nacional de Imunização (PNI), órgão vinculado à União.

Dessa forma, o Tribunal a quo fixou a condenação do pagamento de $\mathrm{R} \$ 50.000,00$, a título de danos morais; e o pagamento de danos materiais, com valor a ser fixado em liquidação de sentença. Entretanto, não vislumbrou a concessão de pensão vitalícia à vítima, em razão da autora não ter perdido a capacidade laborativa, mas apenas ter havido a sua redução.

\section{a.2. Julgamento no Superior Tribunal de Justiça}

Como não logrou provisão completa do seu pedido quanto ao valor e modalidade de indenização nas instâncias ordinárias, coube à vítima interpor o recurso especial ao STJ, pleiteando o arbitramento de pensão vitalícia e a majoração dos danos morais, em razão da perda (parcial e moderada) de sua capacidade laboral.

Sob relatoria do Min. Napoleão Nunes Maia Filho, o acórdão em Recurso Especial n. ${ }^{\circ} 1.514 .775$ - SE (julgado em 10/03/2016) (BRASIL, 2016) sustenta a responsabilidade civil do ente federal para indenizar a vítima de dano (SGB) decorrente de vacina contra a influenza.

Ficou comprovado que a vítima estava acometida da SGB, desenvolvida após a ministração da vacina contra a influenza $\mathrm{A}$, de sorte que as instâncias ordinárias confirmaram a conexão causal entre o seu uso e a emergência do dano.

No julgamento do recurso, o ministro relator ponderou a responsabilidade civil da União, com o dever de indenizar a vítima, com fundamento no $\S 6^{\circ}$, do art. 37 da Constituição Federal, sob a consagração da teoria do risco administrativo, ao estabelecer a responsabilidade civil objetiva do Estado (lato sensu) pelos danos causados em razão da ação ou omissão (ainda que lícita) do ente estatal.

Segundo o relator, a prestação de serviços pelo ente público destina-se ao cidadão. E dessa prestação de serviço público, seja por ente federado, seja sujeito privado, persevera a responsabilidade civil do Estado, uma vez que a atividade desenvolvida pode trazer consigo um risco inerente. Assim, a responsabilidade estatal 
se estende cada vez mais nas áreas em que se faz presente, com fundamento na teoria do risco administrativo, de acordo com o relator.

Outrossim, para fundamentar a responsabilização do ente federado, o relator apresenta todo o aparato legislativo, da seguinte forma:

Afirma que o Programa Nacional de Imunização (PNI), gerenciado pelo Ministério da Saúde, conforme dicção do art. $3^{\circ}$, da Lei n. ${ }^{\circ} 6.259 / 75$, é de inteira responsabilidade da União. Diante disso, a ministração da vacina por entes privados, os obriga a informar à União que mantém todo o controle sobre a circulação da vacina e sobre os seus efeitos adversos.

Cabe também à União, por meio do órgão de vigilância sanitária, que o registro de vacinas, as quais são tratadas no Brasil como medicamentos, segundo o relator, deve atender a requisitos específicos, entre eles, a segurança, eficácia e inocuidade, bem como seja oferecida amplas informações, entre elas, de segurança, conforme especificado no art.16 e seus incisos, da Lei $n^{\circ}$ 6.360/76.

Informa que $o$ art. 14 do Decreto $n^{\circ} 79.094,{ }^{12}$ criado para regulamentar a Lei $n^{\circ} 6.360 / 76$, estabelece que nenhum produto submetido à vigilância sanitária, poderá ser posto em circulação antes do registro no órgão competente. E o registro de vacinas ficará sujeita à comprovação de eficácia e inocuidade (art. 26, inciso I, dec. 79.094/77).

Ressaltou, também, que as vacinas são tratadas como medicamentos e a sua utilização está sob o controle e a fiscalização da Anvisa, de acordo com o art. 16 da Lei n. ${ }^{\circ} 6.360 / 76$.

O relator ressaltou que restou comprovado nos autos, por meio de documentos anexados (extratos de Diários Oficiais da União), que a Anvisa, agência vinculada ao Ministério da Saúde, é a responsável pela autorização do uso das vacinas em solo brasileiro, incluindo-se aquelas aplicadas contra o vírus $\mathrm{H} 1 \mathrm{~N} 1$ reforçando acerca da responsabilidade civil da União no presente caso, o que culminou com a manutenção do acórdão recorrido, no sentido de reconhecer a responsabilidade civil da União por danos causados pela ministração da vacina contra a influenza A, que, em decorrência do seu uso, implicou no acometimento na vítima da síndrome de Guillian-Barré.

O acórdão em exame também se pautou no entendimento adotado pelo Supremo Tribunal Federal (BRASIL, 2012) em caso similar, que reconheceu a responsabilidade da União por indenizar a morte de criança em decorrência de encefalite causada pela vacina contra tríplice (DPT), que continha componente chamado "pertussis". O fundamento usado pelo STF para sustentar a responsabilidade civil do Estado foi o risco administrativo e a conexão causal entre a doença e o fornecimento de uma vacina no âmbito da política pública de saúde. Reiterou que a atividade do ente estatal não pode expor as pessoas a riscos e a ocorrência de danos.

Por fim, o ministro relator reconheceu o cabimento legal de arbitramento da pensão vitalícia à vítima, com fundamento no art. 950, do Código Civil, em razão da redução parcial e permanente de sua capacidade laborativa, independentemente da existência da capacidade para outras atividades, por exigir um maior sacrifício da vítima para desempenhar a atividade laboral.

Por conseguinte, o acórdão majorou o quantum indenizatório por danos morais, sob o critério da extensão do dano, ${ }^{13}$ a desproporcionalidade entre a indenização inicialmente fixada e o dano causado, o grau de ofensa causado à honra da vítima, e, especialmente, o princípio da equidade, com base nos valores arbitrados pelo STJ, o que foi fixado no patamar de $\mathrm{R} \$ 100.000,00$ (cem mil reais).

\section{a.3. Tese divergente - Ministra Regina Helena Costa}

A ministra Regina Helena Costa abriu divergência para o voto do relator Min. Napoleão Nunes Maia Filho, para negar total provimento ao recurso especial, sob o fundamento da necessidade de delimitação da responsabilidade civil do ente federal pela realização da campanha de vacinação. Explicou a ministra que não 
coube à União a produção da vacina, o seu armazenamento, a manipulação ou administração, tornando-se desproporcional e desarrazoada a imputação da responsabilidade exclusiva da União pelo dano causado à vítima.

A ministra observou que o Tribunal a quo não delimitou o nexo de causalidade, hipótese para a discussão da responsabilidade civil do ente federal. Apontou que a vacina no presente caso não foi comprada nem aplicada em postos de saúde ou hospitais federais, mas por ente privado (Intermédica Sistemas de Saúde S/A).

Destarte, a ministra aponta que a única responsabilidade da União é a de incentivar a população a tomar a vacina, durante a Campanha Nacional de Imunização. Em razão disso, considera que não houve nexo de causalidade entre a conduta e o dano no presente caso, pois não houve a atuação de agente público nem a ocorrência de dano, causado em órgãos públicos de saúde.

Salientou, ainda, que foi o laboratório GlaxoSmithKline que produziu a vacina, no entanto, não foi demandado por falta de diligência da parte autora, bem como a aplicação da vacina foi promovida por empresa privada.

Sob essas argumentações, entendeu que a concessão de pensão vitalícia e a majoração do dano moral pelos demais ministros é injusta e desarrazoada, ao imputar a responsabilidade exclusivamente à União, uma vez que o ente federal somente realizou a Campanha Nacional de Imunização.

Dessa forma, segundo o voto de divergência, o dever de indenizar da União está delimitado somente à realização da Campanha Nacional de Imunização, que provocou lesão à vítima, com as reações provocadas pela vacina, que culminaram na paraplegia da vítima. Ademais, asseverou que a Campanha Nacional de Vacinação, realizada pela União, não constitui causa direta e imediata do resultado danoso.

A ministra pugnou pelo indeferimento do pagamento de pensão vitalícia pela União, ao suscitar que as condições de armazenamento da vacina, as quais estavam sob a responsabilidade da empresa Intermédica Serviços de Saúde S/A, poderiam ter ocasionado a alteração dos princípios ativos da vacina, o que estava fora da responsabilidade do ente federal. Assim, afirmou que eventual responsabilidade pelo pagamento da pensão vitalícia deveria ser imputada ao laboratório fabricante da vacina ou à empresa que aplicou a vacina à vítima.

Ao final, votou pelo não provimento do recurso especial, ao delimitar, em suma, que não cabe a atribuição da responsabilidade única e exclusiva à União pelo dano causado à vítima, em razão de outros agentes terem concorrido para o resultado danoso.

Essa tese divergente, negando provimento total ao recurso, foi vencida, prevalecendo a solução proposta pelo relator. O acórdão transitou em julgado em data de 30/10/2019.

\section{b. Recurso Especial n. ${ }^{\circ} 1.388 .197$ - PR (2013/0099928-9)}

\section{b.1. Julgamento nas instâncias ordinárias}

$\mathrm{Na}$ origem, trata-se de ação de indenização por danos materiais e lucros cessantes, pela redução da capacidade laborativa, bem como danos morais, e pagamento de pensão mensal vitalícia, proposta por vítima diagnosticada com SGB, após campanha de vacinação, ajuizada em face da União, do estado do Paraná e da empresa Sanofi Aventis Farmacêutica Ltda.

O autor relata, em sua inicial, que após receber uma dose da vacina contra o vírus da influenza A (gripe), em meados de 2006, em Campanha Nacional de Vacinação de Idosos, desenvolveu a síndrome de GuillianBarré como efeito adverso da vacina contra a gripe. Aduz que, logo após ter se submetido à vacina, sentiu extrema fraqueza e perda da força muscular, o que levou a sua internação em hospital. Os sintomas evoluíram para paralisia total, com perda da função muscular e insuficiência respiratória aguda. Após, foi diagnosticado com SGB, a qual deixou sequelas, pois a vítima alega que perdeu a sua autonomia e mobilidade, motivo pelo qual não consegue andar e tem pouca mobilidade nos membros superiores, bem como perdeu a capacidade laborativa. Ao final, pugnou pela procedência da ação.

O juízo de primeiro grau julgou parcialmente procedente a ação. Em sede preliminar, excluiu do polo passivo a fabricante Sanofi Aventis Farmacêutica Ltda, por ausência de elementos probatórios quanto a sua legitimidade, em razão de se ter comprovado nos autos a possível responsabilidade do Instituto Butantan pela fabricação da vacina contra o vírus da influenza A, utilizada na campanha de vacinação de idosos. Outrossim, 
excluiu-se do polo passivo o estado do Paraná, após ter considerado que o referido ente atuou por delegação, como um longa manus na execução de atividade pertinente ao Ministério da Saúde, embora tenha sido o estado do Paraná que executou a campanha de vacinação na rede pública estadual. Isto é, a ação de vacinação foi realizada por ordens da União, que manifestou o interesse de vacinar aquele público-alvo (idosos), ao adquirir e distribuir as vacinas.

No mérito, o juízo a quo reconheceu a responsabilidade da União, em razão da comprovação do nexo de causalidade entre a conduta do ente federal, ao promover a campanha de vacinação e ter conhecimento dos eventuais efeitos colaterais provocados pela vacina, embora que remotamente, e os danos sofridos pelo autor, ao desenvolver a SGB. Assim, fixou o pagamento de R\$100.000,00 (cem mil reais), a título de danos morais, sob o fundamento do abalo emocional e psicológico sofrido pela vítima, em razão da síndrome adquirida; e o pagamento de lucros cessantes, contados da data da vacinação até a final convalescença, no valor de $\mathrm{R} \$$ 3.500,00 (a remuneração do autor); o pagamento de pensão mensal vitalícia, de até 10 salários mínimos mensais; o pagamento de danos materiais, entre eles, o de despesas médicas, locomoção, fisioterapia e tratamentos necessários.

Inconformada com o referido decisum, a União recorreu ao Tribunal Regional Federal da $4^{\text {a }}$ Região, pugnando, em suma, pela: a) legitimidade passiva do estado do Paraná e da Sanofi Aventis Farmacêutica Ltda. e a solidariedade passiva; b) defende que não foi comprovado o nexo causal; c) o excesso de danos morais, entre outros pedidos.

O Tribunal de origem, sob a relatoria do desembargador Sebastião Ogê Muniz, negou provimento ao recurso de apelação do ente federal, mantendo a sentença recorrida, nos termos de reconhecer a responsabilidade civil da União, sob o fundamento de que a vacina foi estimulada em decorrência de política nacional de imunização, de modo que o ente federal deve ressarcir os danos suportados pela vítima, bem como restou comprovado o nexo causal entre a conduta da União e o dano sofrido pelo o autor. Outrossim, manteve a fixação dos danos morais e materiais, conforme estipulados na sentença recorrida.

\section{b.2. Julgamento no Superior Tribunal de Justiça}

Coube à União interpor recurso especial ao Superior Tribunal de Justiça alegando que outros agentes deveriam ser legitimados no polo passivo da demanda principal, quais sejam, a empresa que produz a vacina e o estado do Paraná; alternativamente, pediu a sua exclusão da demanda, alegando a ausência de comprovação do nexo de causalidade; sustentou que não cabe ao ente federal atender e tratar diretamente os doentes, mas tão somente o repasse de verbas às Secretarias de Saúde dos estados, para executar os serviços públicos de saúde, assim como a realização das campanhas de vacinação; e, por fim, defende a desproporcionalidade da fixação do valor da indenização.

Por decisão da Segunda Turma desta Corte, o Recurso Especial n. ${ }^{0}$ 1.388.197 (BRASIL, 2015) - PR foi julgado em 18/06/2015, em desfavor da União, mantendo-se, na íntegra, o acórdão do Tribunal Regional Federal da $4^{\text {a }}$ Região. Mais uma vez, a Corte reafirmou a responsabilidade civil do Estado em razão de dano causado por efeito adverso da vacina contra a influenza.

Em suas razões, o ministro relator Herman Benjamin, reiterou a importância das vacinas para a saúde pública, a despeito das possíveis reações adversas, as quais podem incapacitar a pessoa e até causar a morte. Mas sustentou que o dever do Estado (lato sensu) de promover a imunização em massa para o bem da saúde pública também impõe o dever de responder pelos efeitos colaterais, garantindo à vítima a justa indenização.

O ministro fundamentou a sua decisão na responsabilidade civil objetiva, com fulcro no art. 927, parágrafo único, do Código Civil e no art. 14 do Código de Defesa do Consumidor, qualificando o incidente como um acidente de consumo em decorrência da vacinação. Descartou a possibilidade de tratar a hipótese como mero caso fortuito ou imprevisibilidade de reações adversas.

Enfatiza-se, por ora, que a tese quanto aos agentes envolvidos na campanha de vacinação, na qual a União destacou a legitimidade passiva do estado do Paraná e da empresa que participou de uma das etapas de produção da vacina, a Sanofi Aventis Farmacêutica Ltda, o relator deixou de apreciar ante a deficiência na 
motivação e a ausência de impugnação do fundamento do acórdão recorrido, conforme aplicação, por analogia, das Súmulas $283^{14}$ e $284^{15}$ do STF.

Igualmente, o ministro relator não analisou o pleito do montante de dano moral e da comprovação do nexo causal, em razão da instância originária ter decidido a controvérsia com base no suporte fático-probatório presente nos autos, o que impede o reexame do contexto fático-probatório, em sede de recurso especial, pelo STJ, conforme previsão da Súmula $7 .{ }^{16}$

O acórdão transitou em julgado em data de 23/06/2017.

\section{Conclusão}

As vacinas são soluções técnicas valiosíssimas para o bem-estar individual e para a saúde coletiva. Afastam os riscos de pandemia e reduzem os riscos de as pessoas serem acometidas por doenças graves e até fatais. Em virtude disso, a vacinação como prática de saúde pública é um avanço inestimável para garantir a população maior qualidade de vida, em completa condição de igualdade. Muitas delas são distribuídas gratuitamente nos postos de saúde pelo SUS. Em virtude de sua importância, a União, por meio do Ministério da Saúde, realiza campanhas anuais para promover a imunização massiva e combater certas doenças, como a influenza A.

Todo esse processo pretende-se muito seguro, pois, antes de ser distribuída no mercado de consumo e utilizada nas políticas públicas em saúde, a vacina é objeto de rigoroso controle para registro junto ao órgão de vigilância sanitária - a Anvisa. Avaliam-se os benefícios e eventuais riscos de efeitos adversos, procurando sopesar para garantir que venham a promover mais vantagens do que prejuízos.

Como a esfera federal conjuga o poder de controle da qualidade pelo registro e a direção das campanhas nacionais para a imunização, converge para a União o dever de responder pelos danos causados às pessoas em virtude do uso da vacina. Considera-se um dano injusto a lesão a interesse protegido, mesmo quando o ato lesivo é considerado lícito.

Outros agentes poderiam ser chamados a responder em conjunto com a União, como o laboratório fabricante da vacina e o seu distribuidor. Na hipótese, porém, seria necessário, antes de tudo, que tais sujeitos estivessem integrando a lide. $\mathrm{E}$, ainda que ficasse comprovado o oferecimento de um produto defeituoso - assim considerado como aquele que não é adequado para o consumo, sendo a vacina regularmente registrada e produzida conforme os ditames normativos, não haveria como qualificá-la como produto defeituoso. Excepcionalmente, esses agentes privados poderiam responder por danos associados se provado o vício de informação, assim considerado como aquele produto que oferece um risco tolerado cuja existência não é informada efetivamente ao consumidor.

De todo modo, prevaleceria, igualmente, a responsabilidade civil da União pelas razões já elencadas acima, ainda mais quando ela própria elenca a SGB como um possível efeito adverso. Além disso, tem sua responsabilidade civil matizada pela teoria do risco administrativo, segundo a qual a atividade estatal não pode resultar em danos.

\section{Referências}

BIANCA, C. Massimo. Diritto civile. Milão: Dott. A. Giuffrè Editore, 1994.

BRASIL. Ministério da Saúde. 21ª Campanha Nacional de Vacinação contra a Influenza. Ministério da Saúde: Brasília, 2019a. Disponível em: http://portalarquivos2.saude.gov.br/images/pdf/2019/fevereiro/28/ Informe-Cp-Influenza-28-02-2019-final.pdf. Acesso em: 12 dez. 2019.

\footnotetext{
4 "Súmula 283/STF: É inadmissível o recurso extraordinário quando a decisão recorrida assenta em mais de um fundamento suficiente e o recurso não abrange todos eles".

15 "Súmula 284/STF: É inadmissível o recurso extraordinário quando a deficiência na sua fundamentação não permitir a exata compreensão da controvérsia."

16 "Súmula 7/STJ: A pretensão de simples reexame de prova não enseja Recurso Especial."
} 
BRASIL. Ministério da Saúde. Síndrome de Guillain-Barré: causas, sintomas, tratamentos e prevenção. Disponível em: http://saude.gov.br/saude-de-a-z/guillain-barre. Acesso em: 13 dez. 2019b.

BRASIL. Ministério da Saúde. Secretaria de Vigilância em Saúde. Informe $\mathbf{n}^{\circ} \mathbf{2 1}$, de 03 de junho 2019. Influenza: monitoramento até a semana epidemiológica 21 de 2019. 2019c. Disponível em: http:// portalarquivos2.saude.gov.br/images/pdf/2019/junho/04/Informe--Influenza-SE-21.pdf. Acesso em: 19 dez. 2019.

BRASIL. Ministério da Saúde. Secretaria de Vigilância em Saúde. Agência Nacional de Vigilância Sanitária. Protocolo de vigilância epidemiológica de eventos adversos pós-vacinação: estratégia de vacinação contra o vírus Influenza Pandêmico (H1N1). Brasília: Ministério da Saúde, 2010. Disponível em: http://portal.anvisa.gov.br/documents/33868/399730/Protocolo+de+Vigil\%C3\%A2ncia+Epidemiol\%C 3\%B3gica+de+Eventos+Adversos+P\%C3\%B3s-Vacina\%C3\%A7\%C3\%A3o/9334e6d9-f301-4cbb-ab393ba07292c651. Acesso em: 19 dez. 2019.

BRASIL. Superior Tribunal de Justiça. Recurso Especial 1.514.775. Administrativo. Campanha Nacional de vacinação Contra Influenza. Adesão voluntária. Incapacidade. Polineuropatia Desmilienizante inflamatória. Pós-vacinal - síndrome de Guilain-barré. Preliminares Afastadas. Responsabilidade da união. [...] Pedido de pensão vitalícia. Improcedência. Capacidade Laborativa Reduzida, porém não extinta. Reparação por danos morais. Possibilidade. Adequação do quantum. Reparação por danos Materiais. Possibilidade [...]. Apelação Parcialmente Provida. Ana Cristina de Carvalho Moura. União. Relator: Min. Napoleão Nunes Maia Filho, 10 mar. 2016. Disponível em: https://ww2.stj.jus.br/processo/ revista/documento/mediado/?componente=ATC\&sequencial $=58557535 \&$ num_registro $=201500265150 \& d$ ata $=20161110 \&$ tipo=51\&formato=PDF. Acesso em: 2 jan. 2020.

BRASIL. Superior Tribunal de Justiça. Recurso Especial 1.388.197. Administrativo. Responsabilidade Civil Objetiva. Acidente de Consumo. Art. 927, Parágrafo Único, do Código Civil. Art. 14 do Código de Defesa do Consumidor. Campanha Nacional de Vacinação de Idosos Contra Vírus Influenza-Gripe. Reação Vacinal. Desenvolvimento da síndrome de Guillain-Barré. Caso fortuito não configurado. Dano moral presumido. Indenização. União. Osmar José Dos Santos. Relator: Min. Herman Benjamin, 18 jun. 2015. Disponível em: https://ww2.stj.jus.br/processo/revista/documento/mediado/?componente=ATC\&sequencial=49149336\&n um_registro=201300999289\&data=20170419\&tipo=41\&formato=PDF. Acesso em: 2 jan. 2020.

BRASIL. Supremo Tribunal Federal. Recurso Extraordinário com Agravo 868.610. Direito Administrativo. Omissão do Poder Público. Responsabilidade objetiva. Elementos da responsabilidade civil estatal demonstrados na origem. Reexame de fatos e provas. Impossibilidade. Precedentes. 1. A jurisprudência da Corte firmou-se no sentido de que as pessoas jurídicas de direito público respondem objetivamente pelos danos que causarem a terceiros, com fundamento no art. 37 , $\S 6^{\circ}$, da Constituição Federal, tanto por atos comissivos quanto por atos omissivos, desde que demonstrado o nexo causal entre o dano e a omissão do Poder Público. 2. Inadmissível, em recurso extraordinário, o reexame de fatos e provas dos autos. Incidência da Súmula n 279/STF. 3. Agravo regimental não provido. Relator Min. Dias Toffoli, 26 de maio de 2015. Disponível em: http://redir.stf.jus.br/paginadorpub/paginador. jsp?docTP=TP\&docID=8831973. Acesso em: 19 dez. 2019.

CAVALIERI FILHO, Sérgio. Programa de responsabilidade civil. São Paulo: Atlas, 2016.

CENTERS FOR DISEASE CONTROL AND PREVENTION (CDC). Preliminary results: surveillance for Guillain-Barre syndrome after receipt of influenza A (H1N1) 2009 monovalent vaccine - United States, 2009-2010. MMWR Morb Mortal Wkly Rep, Atlanta, v. 59, p. 657-661, 2 jun. 2010. Disponível em: https://www.cabdirect.org/cabdirect/abstract/20103180774. Acesso em: 19 dez. 2019.

COORDENAÇÃO GERAL DO PROGRAMA NACIONAL DE IMUNIZAÇÕES. Boletim Informativo. Campanha Nacional de Vacinação contra Influenza, 2017. Disponível em: http://portalarquivos2. saude.gov.br/images/pdf/2017/julho/28/Boletim-Informativo-Campanha-Influenza-2017.pdf. Acesso em: 12 dez. 2019.

DÍEZ-PICAZO, Luis. Derecho de daños. Madrid: Civitas, 1999.

EISEN, Damon P.; MCBRYDE, Emma S. Avoiding Guillan-Barre' Syndrome Following Swine Origin Pandemic H1N1 2009 Influenza Vaccination. The Journal of Infectious Diseases, Oxford, v. 200, n. 10, 
p. 1627-1628, 15 nov. 2009. Disponível em: https://academic.oup.com/jid/article/200/10/1627/881649. Acesso em: 19 dez. 2019

FACCHINI NETO, Eugênio. A relativização do nexo de causalidade e a responsabilização da indústria do fumo: a aceitação da lógica da probabilidade. Civilística.com, Rio de Janeiro, ano 5, n. 1, p. 1-41, 2016. Disponível em: http://civilistica.com/wp-content/uploads/2016/07/Facchini-Neto-civilistica.coma.5.n.1.2016.pdf. Acesso em: 2 jan. 2020.

FELINTO, Gustavo Machado; ESCOSTEGUY, Claudia Caminha; MEDRONHO, Roberto de Andrade. Fatores associados ao óbito dos casos graves de influenza $\mathrm{A}(\mathrm{H} 1 \mathrm{~N} 1)$ pdm09. Cad. Saúde Coletiva, Rio de Janeiro, v. 27, n. 1, p. 11-19, 2019. Disponível em: http://www.scielo.br/pdf/cadsc/v27n1/1414-462Xcadsc-1414-462X201900010433.pdf. Acesso em: 12 dez. 2019.

FERRARINI, Maria Aparecida G. et al. Síndrome de Guillain-Barré em associação temporal com a vacina influenza A. Revista Paulista de Pediatria, São Paulo, v. 29, n. 4, p. 685-688, 2011. Disponível em: http://www.scielo.br/pdf/rpp/v29n4/33.pdf. Acesso em: 19 dez. 2019.

MARQUES, Cláudia Lima. Contratos no Código de Defesa do Consumidor. 4. ed. São Paulo: RT, 2004.

MELO, Celso Antônio. Curso de direito administrativo. 15. ed. São Paulo: Malheiros, 2014.

MINAS GERAIS. Tribunal de Justiça. Apelação Cível n. 10518180076920001. Medida de proteção - direito à saúde - vacinação obrigatória - direito coletivo - melhor interesse do menor - liberdade religiosa - ponderação. [...] Em consideração ao princípio constitucional do melhor interesse, não podem os genitores se recursarem a vacinar os filhos quando se busca alcançar o pleno desenvolvimento daqueles, o que, por certo, envolve o direito à saúde em todas as suas formas, incluídas as de prevenção por meio da vacinação. O interesse do menor se sobrepõe a qualquer interesse particular dos genitores. A imposição da imunização não fere o direito à liberdade religiosa, uma vez que não sendo esse absoluto, é passível de ponderação e, assim, não há se falar no direito de escolha dos pais, mas no direito da criança à saúde. Apelação Cível n 1.0518.18.007692-0/001. Relator: Des. Dárcio Lopardi Mendes. Poços de Caldas, MG, 12 de dezembro de 2019. Disponível em: https://www5.tjmg.jus.br/ jurisprudencia/pesquisaNumeroCNJEspelhoAcordao.do?numeroRegistro=1\&totalLinhas $=1$ \&linhasPorPa gina=10\&numeroUnico=1.0518.18.007692-0\%2F001\&pesquisaNumeroCNJ=Pesquisar. Acesso em: 20 dez. 2019.

MORAES, Maria Celina Bodin. Danos à pessoa humana: uma leitura civil-constitucional dos danos morais. Rio de Janeiro: Renovar, 2003.

PEREIRA, Caio Mário da Silva. Responsabilidade civil. Comentários de Gustavo Tepedino. 11. ed. Rio de Janeiro: Forense, 2016.

PERLINGIERI, Pietro. Direito civil na legalidade constitucional. Tradução: Maria Cristina De Cicco. Rio de Janeiro: Renovar, 2011.

RIO GRANDE DO SUL. Tribunal de Justiça. Apelação Cível n. 70016845349. Responsabilidade Civil. Morte de fumante que iniciou o vício do tabagismo antes da vigência do cdc. Responsabilidade objetiva do fabricante ou fornecedor pelo fato do produto (Art. $6^{\circ}$, Inciso vi, $9^{\circ} \mathrm{E}$ Art. 12, Do Cdc). Direito comparado. Pressupostos. Defeito de produto inerentemente perigoso em razão da violação de uma legítima expectativa de segurança capaz de provocar danos á saúde dos consumidores. Nexo de causalidade sob a perpectiva médica e jurídica. Ausência de boa-fé em razão da omissão em alertar aos consumidores de cigarros sobre os conhecidos danos à sáude pelo ato de fumar produto inerentemente perigoso. Contribuição da vítima. Quantum indenizatório. Acórdão No 70016845349 2006/Cível. Relator: Desembargador Odone Sanguiné12 de dezembro de 2007. Disponível: http://actbr.org.br/uploads/ arquivo/169_RS70016845349merito.pdf. Acesso em: 2 jan. 2020.

RODOTÁ, Stefano. II problema della responsabilitá civile. Milano: Giufrè, 1967.

ROSENVALD, Nelson; FARIAS, Cristiano Chaves de; BRAGA NETO, Felipe Peixoto. Curso de direito civil: responsabilidade civil. Salvador: JusPODIVM, 2019.

SCHREIBER, Anderson. Novos paradigmas da responsabilidade civil: da erosão dos filtros da reparação à diluição dos danos. São Paulo: Atlas, 2015. 
SOCIEDADE BRASILEIRA DE CLÍNICA MÉDICA. EUA viveram surto de gripe suína em 1976: vacina gerou mortes. [S.I.]: SBCM, 2015. Disponível em: http://www.sbcm.org.br/v2/index.php/noticias/noticiasda-saude/1018-sp-2125853431. Acesso em: 12 dez. 2019.

SOUZA, Eduardo Nunes de. Merecimento de tutela: a nova fronteira da legalidade no direito civil.

Revista de Direito Privado, São Paulo, v. 15, n. 58, abr.-jun./2014. p. 75-107.

TEPEDINO, Gustavo. Crise de fontes normativas e técnica legislativa na Parte Geral do Código Civil de 2002. In: TEPEDINO, Gustavo (coord.). O código civil na perspectiva civil-constitucional. Rio de Janeiro: Renovar, 2013. p. 01-18.

TEPEDINO, Gustavo. A tutela da personalidade no ordenamento civil-constitucional brasileiro. In:

TEPEDINO, Gustavo (coord.). Temas de direito civil. 2. ed. Rio de Janeiro: Renovar, 2001. p. 23-54.

THOMÉ, Clarissa. Síndrome Guillain-Barré terá notificação compulsória no Rio. Estadão, São Paulo, 06 fev. 2016, Caderno Saúde. Disponível em: https://saude.estadao.com.br/noticias/geral,guillain-barredeveria-ter-notificacao-obrigatoria,10000017158. Acesso em: 13 dez. 2019.

USTARROZ, Daniel. Responsabilidade por ato lícito. São Paulo: Atlas, 2014.

ZAREMBA, Júlia. H1N1 causou a maioria das 222 mortes por gripe em 2019. Folha de S. Paulo, São Paulo, 11 jun. 2019. Disponível em: https://www1.folha.uol.com.br/cotidiano/2019/06/h1n1-causou-amaioria-das-222-mortes-por-gripe-em-2019.shtml. Acesso em: 02 dez. 2019.

\section{Autoras convidadas.}

